\title{
Protein synthesis of the pro-inflammatory S100A8/A9 complex in plasmacytoid dendritic cells and cell surface S100A8/A9 on leukocyte subpopulations in systemic lupus erythematosus
}

\author{
Christian Lood ${ }^{1,2^{*}}$, Martin Stenström³ ${ }^{3}$, Helena Tydén², Birgitta Gullstrand ${ }^{1}$, Eva Källberg ${ }^{3}$, Tomas Leanderson ${ }^{3}$, \\ Lennart Truedsson', Gunnar Sturfelt ${ }^{2}$, Fredrik Ivars ${ }^{3}$ and Anders A Bengtsson ${ }^{2}$
}

\begin{abstract}
Introduction: Systemic lupus erythematosus (SLE) is an autoimmune disease with chronic or episodic inflammation in many different organ systems, activation of leukocytes and production of pro-inflammatory cytokines. The heterodimer of the cytosolic calcium-binding proteins S100A8 and S100A9 (S100A8/A9) is secreted by activated polymorphonuclear neutrophils (PMNs) and monocytes and serves as a serum marker for several inflammatory diseases. Furthermore, S100A8 and S100A9 have many pro-inflammatory properties such as binding to Toll-like receptor 4 (TLR4). In this study we investigated if aberrant cell surface S100A8/A9 could be seen in SLE and if plasmacytoid dendritic cells (pDCs) could synthesize S100A8/A9.
\end{abstract}

Methods: Flow cytometry, confocal microscopy and real-time PCR of flow cytometry-sorted cells were used to measure cell surface S100A8/A9, intracellular S100A8/A9 and mRNA levels of S100A8 and S100A9, respectively.

Results: Cell surface S100A8/A9 was detected on all leukocyte subpopulations investigated except for T cells. By confocal microscopy, real-time PCR and stimulation assays, we could demonstrate that pDCs, monocytes and PMNs could synthesize S100A8/A9. Furthermore, pDC cell surface S100A8/A9 was higher in patients with active disease as compared to patients with inactive disease. Upon immune complex stimulation, pDCs up-regulated the cell surface S100A8/A9. SLE patients had also increased serum levels of S100A8/A9.

Conclusions: Patients with SLE had increased cell surface S100A8/A9, which could be important in amplification and persistence of inflammation. Importantly, pDCs were able to synthesize S100A8/A9 proteins and up-regulate the cell surface expression upon immune complex-stimulation. Thus, S100A8/A9 may be a potent target for treatment of inflammatory diseases such as SLE.

\section{Introduction}

Systemic lupus erythematosus (SLE) is an autoimmune disease characterized by inflammation in several organ systems, B cell hyperactivity, autoantibodies, complement consumption and an ongoing type I interferon (IFN) production $[1,2]$. SLE patients usually have more activated peripheral blood mononuclear cells (PBMCs) in circulation than healthy individuals and there are numerous

\footnotetext{
* Correspondence: christian.lood@med.lu.se

'Department of Laboratory Medicine, Section of Microbiology, Immunology and Glycobiology, Lund University, Sölvegatan 23, 22362 Lund, Sweden Full list of author information is available at the end of the article
}

investigations demonstrating abnormalities in different subpopulations which illustrate the complexity of the pathogenesis in this disease. Increased numbers of plasma cells $[3,4]$, HLA-DR $^{+}$T cells $[5,6]$ and decreased numbers of circulating dendritic cells $[7,8]$ have been reported. Pro-inflammatory $\mathrm{CD} 16^{+}$monocytes have been described to be increased in rheumatoid arthritis but are so far not investigated in SLE [9].

The IFN-alpha (IFN $\alpha$ ) production in SLE is detectable in serum [10], and over-expression of IFN $\alpha$-regulated genes, termed the type I IFN signature, has also been demonstrated in PBMCs [11-16] as well as in platelets 
[17]. In mice, type I IFNs induce lymphopenia through redistribution of the lymphocytes [18] and there is an inverse correlation between serum IFN $\alpha$ and leukocyte count in humans [10]. SLE patients have circulating immune complexes (ICs), which often contain RNA or DNA $[19,20]$. ICs could be endocytosed by the natural IFN $\alpha$ producing cells, the plasmacytoid dendritic cells (pDCs) and induce IFN $\alpha$ production through Toll-like receptor (TLR) 7 or TLR9 stimulation [21,22], which is considered to have a key role in the pathogenesis of SLE [23]. IFN $\alpha$ has many immunomodulatory functions such as inducing monocyte maturation [24], increasing IFNa production from NK cells [25], prolonging the survival of activated $\mathrm{T}$ cells [26] and differentiating $\mathrm{B}$ cells to plasma cells [27].

S100A8 and S100A9 are members of the calciumbinding S100-protein family and are released at inflammatory sites by phagocytes as a complex (S100A8/A9; also called calprotectin or MRP8/14) [28]. Several pro-inflammatory properties have been described for the S100A8/A9 complex, such as activation of monocytes [29], amplification of cytokine production [30], regulation of migration of myeloid derived suppressor cells [31] and, as demonstrated recently, a ligand for receptor for advanced glycation end products (RAGE) and TLR4 [32]. Patients with SLE have increased serum levels of S100A8/A9 [33,34] and the concentration correlates with disease activity. Here we have investigated the portion and activation status of several leukocyte subpopulations and measured cell surface S100A8/A9 on these cells, corresponding S100A8 and S100A9 mRNA expression as well as serum levels of S100A8/A9 in healthy controls and SLE patients to learn more about the role of these proteins in SLE.

\section{Materials and methods \\ Patients}

SLE patients were recruited from an ongoing prospective control program at the Department of Rheumatology, Skåne University Hospital, Lund, Sweden. Blood samples were taken at their regular visits. Healthy subjects, age-matched to the patients, were used as controls. An overview of clinical characteristics is presented in Tables 1 and 2. Disease activity was assessed using SLEDAI-2K [35]. The following SLE treatments were used at the time point of blood sampling: hydroxychloroquine $(n=38)$, azathioprine $(n=17)$, mycophenolatmofetil $(n=11)$, rituximab (within the last 12 months, $n=5)$, methotrexate $(n=4)$, cyclosporine A $(n=3)$, cyclophosphamide $(n=2)$, chloroquine phosphate $(n=$ 1 ) and intravenous immunoglobulins $(n=1)$. All patients fulfilled at least four American College of
Table 1 Clinical characteristics of the SLE patients at the time point of blood sampling

\begin{tabular}{lcc}
\hline Characteristics & SLE $(\boldsymbol{n}=\mathbf{6 3})$ & Control $(\boldsymbol{n}=\mathbf{3 3})$ \\
\hline Age, median (range), years & $42(19$ to 81$)$ & $45(24$ to 79$)$ \\
Female, \% & 94 & 85 \\
Male, \% & 6 & 15 \\
Disease duration, median & $8(0$ to 45$)$ & - \\
(range), years & & - \\
SLEDAl score, median (range) & 2 (0 to 18) & - \\
Seizure & 0 & - \\
Psychosis & 0 & - \\
Organic brain syndrome & 0 & - \\
Visual disturbance & 1 & - \\
Cranial nerve disorder & 1 & - \\
Lupus headache & 0 & - \\
Cerebrovascular accident & 0 & - \\
Vasculitis & 3 & - \\
Arthritis & 8 & - \\
Myositis & 1 & - \\
Kidney involvement (urinary & 14 & - \\
cast, hematuria, proteinuria or & & - \\
pyuria) & & - \\
Mucocutaneous activity (rash, & 12 & - \\
alopecia or mucosal ulcers) & & - \\
Pleurisy & 0 & - \\
Pericarditis & 0 & - \\
Low complement (C3 or C4) & 14 & - \\
Anti-DNA antibodies & 14 & - \\
Fever & 2 & - \\
Lhrombocytopenia & 1 & - \\
\hline & 2 & - \\
\hline
\end{tabular}

Items included in SLE disease activity (SLEDAI) are shown.

Rheumatology (ACR) 1982 criteria for SLE [36]. The study was approved by the regional ethics board (LU 378-02). Informed consent was obtained from all participants.

\section{Antibodies and reagents}

The following antibodies and reagents were used in the flow cytometry analysis of the patients and the healthy volunteers: anti-CD3-Alexa 647, anti-CD4-APC-Cy7, anti-CD19-Pacific Blue, anti-CD14-PE-Cy7 (all from BioLegend, San Diego, CA, USA), anti-CD3-APC-Alexa Fluor 750, anti-CD8-PE-Cy7, anti-HLA-DR-Alexa Fluor 700, anti-CD20-PE, anti-CD38-PE-Cy5, anti-CD27-Alexa Fluor 700 (all from eBioscience, San Diego, CA, USA), propidium iodide, anti-IgD-FITC, anti-CD16-PE-Cy5, mouse IgG1-FITC (all from BD Biosciences Pharmingen, San Diego, CA, USA), anti-BDCA-1-biotin, anti-BDCA2-PE (both from Miltenyi Biotec Inc., Auburn, CA, USA), anti-S100A8/A9-FITC (27E10, BMA Biomedicals, Rheinstrasse, Switzerland) and streptavidin Qdot-605 (Invitrogen, Carlsbad, CA, USA). 
Table 2 Clinical characteristics of the SLE patients ( $n=63)$ according to ACR 1982 criteria

\begin{tabular}{ll}
\hline ACR criteria & Portion of patients (\%) \\
\hline Malar rash & 65 \\
Discoid rash & 25 \\
Photosensitivity & 67 \\
Oral ulcers & 29 \\
Arthritis & 79 \\
Serositis & 52 \\
Renal disease & 48 \\
Neurological disorder & 6 \\
Hematological manifestation & 54 \\
$\quad$-Leukopenia & 41 \\
$\quad$-Lymphopenia & 24 \\
-Thrombocytopenia & 24 \\
Immunology & 79 \\
$\quad$-a-DNA & 59 \\
ANA & 100 \\
\hline
\end{tabular}

ACR, American College of Rheumatology; ANA, anti-nuclear antibodies.

\section{Flow cytometry}

Blood was drawn into cell preparation tubes (BD Biosciences Pharmingen) and PBMCs were isolated on Lymphoprep ${ }^{\mathrm{TM}}$ according to manufacturer's instructions (Axis-Shield PoC AS, Oslo, Norway). PBMCs $\left(1 \times 10^{6}\right.$ cells) were incubated with $10 \%$ mouse serum in phosphate buffered saline pH 7.2 (PBS) at a total volume of $50 \mu \mathrm{l}$ for 20 minutes at $4^{\circ} \mathrm{C}$. The cells were washed in PBS (200 g 2 minutes) and incubated with biotinylated antibodies for 20 minutes at $4^{\circ} \mathrm{C}$. The cells were washed twice and then incubated for another 20 minutes at $4^{\circ} \mathrm{C}$ with dye-conjugated antibodies and streptavidin-Qdot 605 . Finally, the cells were washed twice and resuspended in $300 \mu \mathrm{l}$ PBS before analysis in the FACSAria (BD Biosciences Pharmingen).

\section{Confocal microscopy}

$\mathrm{T}$ cells, monocytes and pDCs were isolated with negative isolation kits according to manufacturer's instructions (Miltenyi Biotec Inc). Neutrophils were isolated by density gradient centrifugation on Polymorphprep ${ }^{\mathrm{TM}}$ according to the manufacturer's protocol (Axis-Shield PoC AS). $B$ cells and $\mathrm{mDCs}$ were isolated using a FACSAria cell sorter. B cells were labeled with Pacific Blue-conjugated CD19 antibodies and mDCs were labeled with both Alexa 700-conjugated HLA-DR antibodies and FITCconjugated BDCA-1 antibodies. Purified cells $\left(8 \times 10^{4}\right)$ were fixed with $4 \%$ paraformaldehyde and permeabilized in $0.2 \%$ TritonX-100 (Sigma, St. Louis, MO, USA) before incubated with PE-conjugated anti-S100A8/A9 antibodies (27E10, Santa Cruz Biotechnology, Santa Cruz, CA, USA) for 30 minutes. The cells were washed once in PBS and transferred to a glass slide (In Vitro, Braunschweig,
Germany) by cytospin for two minutes at a speed of 1,000 g in a Shandon Cytospin 3 (Life Science International LTD, Cheshire, UK). The cells were analyzed in a LSM 510 META microscope (Carl Zeiss, Göttingen, Germany). Fluorescence was detected with pinhole settings corresponding to one airy unit.

\section{Immune complex stimulation of plasmacytoid dendritic cells}

Isolated pDCs $\left(2 \times 10^{4}\right.$ cells $)$ were cultured in $100 \mu \mathrm{l}$ Macrophage-SFM (Invitrogen) supplemented with $20 \mathrm{mM}$ HEPES (Invitrogen), $50 \mu \mathrm{g} / \mathrm{ml}$ Gentamicin (Invitrogen), $2 \mathrm{ng} / \mathrm{ml}$ GM-CSF (Leukine ${ }^{\circledR}$; Berlex, Montville, NJ, USA) and $500 \mathrm{U} / \mathrm{ml}$ IntronA (SP company, Innishannon, Ireland) and incubated for $20 \mathrm{~h}$ at $37^{\circ} \mathrm{C}$ with $5 \% \mathrm{CO}_{2}$ and 97\% humidity with RNA-containing ICs prepared as described previously [37]. Briefly, anti-ribonuclear protein (RNP)-positive sera were pooled and IgG was purified on a protein G column (Protein G Superose HR 10/2, Pharmacia LKB, Uppsala, Sweden). To create ICs, purified IgG at a concentration of $0.25 \mathrm{mg} / \mathrm{ml}$ was mixed with necrotic material from Jurkat cell supernatant at a concentration of $5 \%(\mathrm{v} / \mathrm{v})$. The cells were washed and resuspended in PBS with anti-CD123-FITC (Miltenyi Biotech) and antiS100A8/A9-PE (Santa Cruz Biotechnology) antibodies for 30 minutes at $4^{\circ} \mathrm{C}$ before analyzed by flow cytometry. The ICs used in the experiments contained undetectable amounts $(<40 \mathrm{ng} / \mathrm{ml})$ of S100A8/A9 as measured by the in-house ELISA (data not shown). As a negative control, PE-conjugated mouse IgG1 antibodies were used.

\section{Serum S100A8/A9 detection}

For detection of S100A8/A9, microtitre plates (Maxisorp, Nunc, Roskilde, Denmark) were coated with monoclonal antibody MRP8/14 (27E10, BMA Biomedicals) at a concentration of $5 \mu \mathrm{g} / \mathrm{ml}$, diluted in PBS at a volume of $100 \mu \mathrm{l} /$ well, and incubated at $4^{\circ} \mathrm{C}$ over night. The 27E10 antibody detects a specific epitope of S100A8/A9 which is not exposed on the individual subunits. Between every following step, the plate was washed for three times in PBS containing $0.05 \%$ Tween 20 . After blocking the plate with $1 \%$ BSA in PBS for $1 \mathrm{~h}$, serum samples, diluted 1/100 in sample buffer (0.15 M NaCl, $10 \mathrm{mM}$ HEPES (Invitrogen), $1 \mathrm{mM} \mathrm{CaCl}_{2}, 0.02 \mathrm{mM} \mathrm{ZnCl}_{2}, 0.05 \%$ Tween 20 and $0.1 \%$ BSA), were added at a final volume of $100 \mu \mathrm{l} /$ well and incubated for $2 \mathrm{~h}$ at room temperature under agitation. Biotinylated anti-MRP8/14 (Abcam, Cambridge, UK), diluted 1/2000 in sample buffer, were added at a volume of $100 \mu \mathrm{l} /$ well, and incubated at $4^{\circ} \mathrm{C}$ over night. Bound MRP8/14 antibody was detected with alkaline-phosphatase-labelled streptavidin (Dako, Glostrup, Denmark) diluted 1/1000 in sample buffer. After incubation for $1 \mathrm{~h}$ at room temperature under agitation, the enzymatic reaction was developed with $1 \mathrm{mg} / \mathrm{ml}$ disodium- $p$-nitrophenyl 
phosphate (Sigma) dissolved in 10\% (w/v) dietanolamine $\mathrm{pH} 9.8$ containing $50 \mathrm{mM} \mathrm{MgCl}_{2}$ and the absorbance was measured at $405 \mathrm{~nm}$. S100A8/A9 content of one serum sample was quantified using a commercial S100A8/A9 kit (BMA Biomedicals) and used as an internal control. The values reported are means of duplicates with the background subtracted and the concentrations were calculated from titration curves obtained from a pool of normal human serum.

\section{Real-time PCR}

Isolated PBMC from healthy donors were stained with anti-CD3-Alexa 647, anti-CD19-Pacific Blue, anti-CD14PECy7, anti-CD16-FITC, anti-HLA-DR-Alexa 700, antiBDCA-1-biotin and anti-BDCA-2-PE antibodies and sorted on a FACSAria before frozen at $-80^{\circ} \mathrm{C}$ in lysis buffer. Total RNA was extracted by Purelink RNA mini Kit (Invitrogen, Carlsbad, CA, USA) and reversely transcribed to cDNA by SuperScript II Platinum synthesis system (Invitrogen) according to manufacturer's instructions. Ribosomal protein L4 (RPL4), S100A8 and S100A9 mRNA were quantified by real-time PCR using the SYBR GreenER kit (Invitrogen) in a MYIQ PCR machine (Bio-Rad, Hercules, CA, USA). The threshold cycle number and levels of each mRNA were determined using the formula $2(\mathrm{Rt}-\mathrm{Et})$, where $\mathrm{Rt}$ is the threshold cycle for the housekeeping gene RPL-4 and Et the threshold cycle for the gene of interest.

\section{Statistics}

Data were evaluated with analysis of variance (ANOVA) when comparing healthy controls with SLE patients or within the patient cohort when evaluating different disease manifestations. SAS version 9.2 for Windows XP (SAS Institute Inc., Cary, NC, USA) was used in the statistical evaluation. Correlations were calculated by Spearman rank correlation test without adjustment for multiple testing. All $P$-values were considered significant at $P<0.05$.

\section{Results}

\section{SLE patients have more activated leukocytes}

First, we wanted to confirm abnormalities in PBMCs from SLE patients described by others to validate our patient material. Over all, SLE patients had markedly decreased cell density of PBMCs as compared to healthy controls (median SLE: $0.41 \times 10^{6}(0.40$ to 0.51$)$ cells $/ \mathrm{ml}$ and median healthy controls $1.00 \times 10^{6}(0.86$ to 1.12$)$ cells $/ \mathrm{ml}, P<0.0001)$. A summary of all investigated leukocyte populations is shown in Table 3. SLE patients had more activated cells with increased HLA-DR expressing $\mathrm{CD}^{+} \mathrm{T}$ cells $(P=0.001), \mathrm{CD}^{+} \mathrm{T}$ cells $(P=$ $0.02)$, pro-inflammatory $\mathrm{CD} 16^{+}$monocytes $(P=0.003)$ and percentage of plasma cells $(P<0.0001)$, as compared to healthy controls. Altogether we have demonstrated that SLE patients have more activated leukocytes as compared to healthy controls and these results are in concordance with previous findings $[3,5]$.

\section{S100A8/A9 is detected on several different cell populations}

Detection of S100A8/A9 has previously been demonstrated on the surface of monocytes [32] as well as intracellularly in polymorphonuclear cells [28]. We wanted to see if S100A8/A9 was also present on other cells since our main objective was to investigate possible aberrant expression in SLE. We could detect S100A8/A9 on naïve as well as pro-inflammatory monocytes, PMNs, B cells, myeloid dendritic cells (mDCs) and pDCs in both SLE patients and healthy controls (Figure 1). However, S100A8/A9 could not be detected on $T$ cells where the mean fluorescence index (MFI) ratio indicated little or no cell surface S100A8/A9. Levels of the cell surface S100A8/A9 correlated well in samples from the same individual between the different cell populations (data not shown). Treatment with immunosuppressive drugs at the time of blood sampling was not statistically significantly associated with altered cell surface S100A8/A9. Cell surface S100A8/A9 was not significantly increased in SLE patients as a whole when compared to healthy controls on any cell population investigated (data not shown). We then investigated if cell surface S100A8/A9 was altered in patients with active disease (defined as SLEDAI $\geq 4$ ) as compared to patients with inactive disease (SLEDAI < 4). Patients with active disease had increased cell surface S100A8/A9 on their $\mathrm{CD} 16^{+}$pro-inflammatory monocytes, pDCs, $\mathrm{mDCs}$ as well as PMNs as compared to SLE patients with inactive disease $(P=0.0005$, $P=0.006, P=0.03$ and $P=0.015$, respectively) and increased cell surface S100A8/A9 on their CD16 ${ }^{+}$proinflammatory monocytes and PMNs as compared to healthy controls $(P=0.0065$ and $P=0.034$, respectively, Figure 1). Thus we could demonstrate that cell surface S100A8/A9 was associated with disease activity and increased in patients with active disease.

\section{S100A8 and S100A9 are not produced by all leukocytes}

Since S100A8/A9 was observed on most cell populations we wanted to know if this was due to expression of the S100A8 and S100A9 genes or due to deposition from external sources. To test the first possibility S100A8 and S100A9 mRNA levels were analyzed in FACS-sorted cells. Only low mRNA levels were found in T cells, B cells and $\mathrm{mDCs}$, despite detection of cell surface S100A8/A9 on B cells and mDCs. However, clearly detectable levels of both S100A8 and S100A9 mRNA were found in monocytes, PMNs and pDCs (Figure 2A). These results confirm that S100A8/A9 is mainly 
Table 3 Frequencies of different cell populations in SLE patients and healthy controls

\begin{tabular}{|c|c|c|c|}
\hline Cell population & Healthy controls (median and $95 \% \mathrm{Cl})^{1}$ & SLE patients (median and $95 \% \mathrm{Cl}$ ) & $P$-value \\
\hline $\mathrm{CD}^{+} \mathrm{T}$ cells & $60.9(57.8$ to 63.9$)$ & $65.1(55.7$ to 64.3$)$ & 0.42 \\
\hline $\mathrm{CD}^{+} \mathrm{T}$ cells & $62.1(57.0$ to 64.7$)$ & $55.2(51.3$ to 58.9$)$ & 0.06 \\
\hline $\mathrm{CD}^{+}{ }^{+} \mathrm{HLA}-\mathrm{DR}^{+}$ & 6.5 (5.3 to 7.2$)$ & 31.3 (24.9 to 36.9$)$ & 0.001 \\
\hline $\mathrm{CD8}^{+} \mathrm{T}$ cells & $15.7(14.3$ to 18.8$)$ & 20.4 (18.6 to 24.0$)$ & 0.02 \\
\hline $\mathrm{CD}^{+} \mathrm{HLA}^{-\mathrm{DR}^{+}}$ & 40.8 (39.0 to 43.2$)$ & 36.9 (33.4 to 41.5$)$ & 0.33 \\
\hline $\mathrm{BDCA}^{-1^{+}} \mathrm{mDCs}$ & 0.40 (0.34 to 0.46$)$ & 0.31 (0.28 to 0.62$)$ & 0.19 \\
\hline 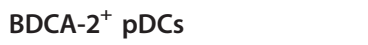 & 0.07 (0.07 to 0.11$)$ & 0.09 (0.09 to 0.16$)$ & 0.39 \\
\hline $\mathrm{CD} 14^{++} \mathrm{CD} 16^{-}$monocytes & 10.1 (9.6 to 13.3$)$ & 16.9 (16.0 to 25.2$)$ & 0.013 \\
\hline $\mathrm{CD} 14^{++} \mathrm{CD} 16^{+}$monocytes & 0.17 (0.15 to 0.27$)$ & 0.30 (0.44 to 0.81$)$ & 0.003 \\
\hline $\mathrm{CD}_{19}^{+} \mathrm{B}$ cells & $5.6(4.7$ to 6.3$)$ & $5.1(5.0$ to 7.8$)$ & 0.78 \\
\hline $\mathrm{CD}_{19^{+} \mathrm{CD} 27^{+} \mathrm{IgD}} \mathrm{CD} 38^{+} \mathrm{CD} 20^{-}$ & $0.43(0.35$ to 0.75$)$ & $1.0(0.8$ to 3.0$)$ & $<0.0001$ \\
\hline
\end{tabular}

${ }^{1}$ For $\mathrm{CD}^{+} \mathrm{T}$ cells, dendritic cells, monocytes and B cells the percentage is calculated against the total leukocyte count. For all subpopulations, the percentage is calculated against the main population (for example, $\mathrm{CD} 4^{+} \mathrm{T}$ cells for all $\mathrm{CD} 4^{+} \mathrm{T}$ cell analyses).

$\mathrm{Cl}$, confidence interval; HLA, human leukocyte antigen; $\mathrm{mDC}$, myeloid dendritic cell; $\mathrm{pDC}$, plasmacytoid dendritic cell

produced by monocytes, PMNs and also by pDCs and the cell surface S100A8/A9 on other cell populations is most likely due to external deposition. We could confirm our flow cytometry data using confocal microscopy where we could detect membrane-associated S100A8/ A9 on PMNs, monocytes and pDCs but not on T cells, mDCs or B cells (Figure 3). However, when using a non-confocal setting both $\mathrm{mDCs}$ and $\mathrm{B}$ cells had a weak S100A8/A9 staining whereas $\mathrm{T}$ cells still were negative (data not shown). In addition, we could detect S100A8/ A9 with intracellular location in PMNs, monocytes and pDCs further supporting S100A8/A9 protein synthesis by these cells (Figure 3). Altogether, these data demonstrate that besides monocytes and PMNs, pDCs are also able to produce S100A8/A9.

\section{Increased levels of serum S100A8/A9 in SLE}

If the presence of S100A8/A9 on the cell surface were due to external deposition, the level of cell surface S100A8/A9 might correlate with S100A8/A9 serum concentration. We found that S100A8/A9 serum concentrations were clearly increased in SLE as compared to healthy controls $(P<0.0001$, Figure $2 \mathrm{~B})$, in accordance with previous published results [33,34]. Furthermore, we also found the most pronounced increased serum concentrations of S100A8/A9 in patients with arthritis $(P=$ 0.016), as was previously reported [33], as well as in patients with kidney involvement $(P=0.026)$. There was also a statistically significant correlation between serum concentration of S100A8/A9 and SLEDAI $(P<0.0001, \mathrm{r}$ $=0.49$ ). However, serum S100A8/A9 level correlated only with cell surface S100A8/A9 in PMNs $(P=0.027, \mathrm{r}$ $=0.28$ ) and not cell surface S100A8/A9 levels on other leukocyte subpopulations. Thus, we could demonstrate that SLE patients had increased serum levels of S100A8/ A9 which correlated to disease activity, but there were no strong correlations between S100A8/A9 cell surface levels and serum levels.

We also investigated whether it was possible to deposit S100A8/A9 on leukocytes in vitro. Neither recombinant S100A8/A9 nor serum containing high concentrations of S100A8/A9 (> 5,000 ng/ml) gave any increased surface staining of S100A8/A9 (data not shown). This might suggest that the S100A8/A9 binding ligands were already saturated and that other mechanisms could also be involved in the deposition of S100A8/A9 on the cell surface.

\section{Increased pDC cell surface S100A8/A9 upon activation}

The flow cytometry data in combination with mRNA expression and confocal microscopy data strongly supported that monocytes, PMNs and also pDCs could produce S100A8/A9. Since the pDC is central in SLE pathogenesis and S100A8/A9 production is, to our knowledge, previously only described in monocytes and PMNs, we wanted to further investigate this subpopulation. When stimulating isolated pDCs with ICs in a serum-free medium the cell surface S100A8/A9 increased (Figure 2C) supporting that pDCs are able to synthesize S100A8/A9 and actively transport S100A8/A9 to the cell surface upon activation. Thus, pDCs could up-regulate cell surface S100A8/A9 in response to activation and we propose that pDCs are also able to synthesize S100A8/A9 proteins.

\section{Discussion}

SLE is a heterogeneous disease with involvement of virtually all organ systems, including the skin, joints and kidney. $\mathrm{T}$ and $\mathrm{B}$ cell activation, production of autoantibodies, formation of ICs and the subsequent tissue damage if the immune complexes are not handled correctly are all well described important events in the SLE pathogenesis. Also, many other cell populations besides 


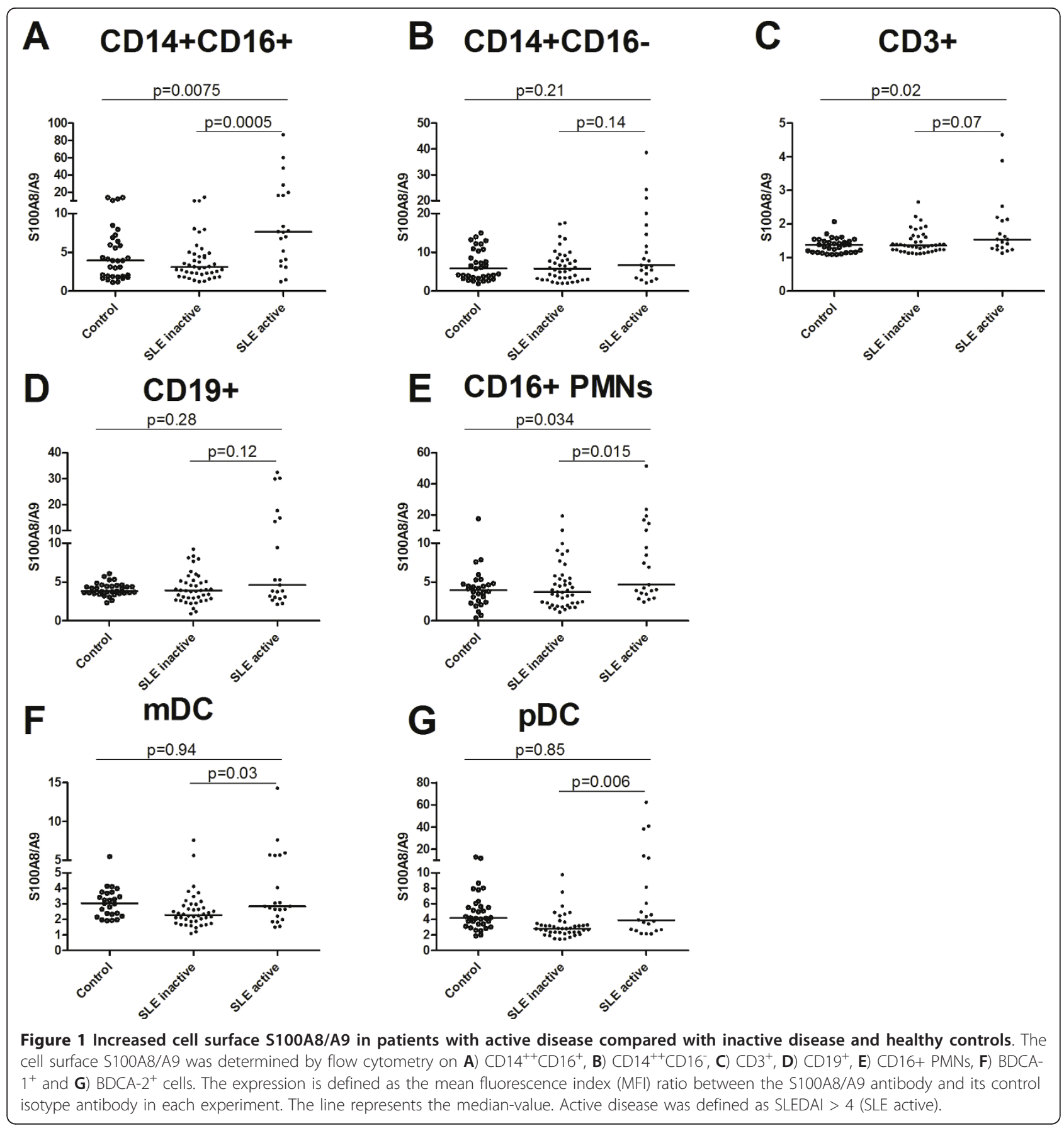

$\mathrm{T}$ and $\mathrm{B}$ cells are activated as demonstrated in this as well as in many other studies [3-8,38]. We found that SLE patients had an increased percentage of plasma cells as well as increased expression of HLA-DR on their $\mathrm{T}$ cells as demonstrated previously [4-6]. Proinflammatory $\mathrm{CD} 16^{+}$monocytes have increased potential to produce pro-inflammatory cytokines such as TNF $\alpha$ [39] and are increased in inflammatory diseases, such as rheumatoid arthritis [9]. We could demonstrate an increased percentage of $\mathrm{CD} 16^{+}$pro-inflammatory monocytes also in SLE. Altogether, we have seen pathological changes with increased activation of $\mathrm{B}$ cells, $\mathrm{T}$ cells and monocytes in SLE patients and it should be noted that these very clear cut pathological changes were also seen in many patients with low disease activity. Although similar observations have been reported by others, our cellular analyses serve as a validation of methods and patient material used in this study. Also, it 


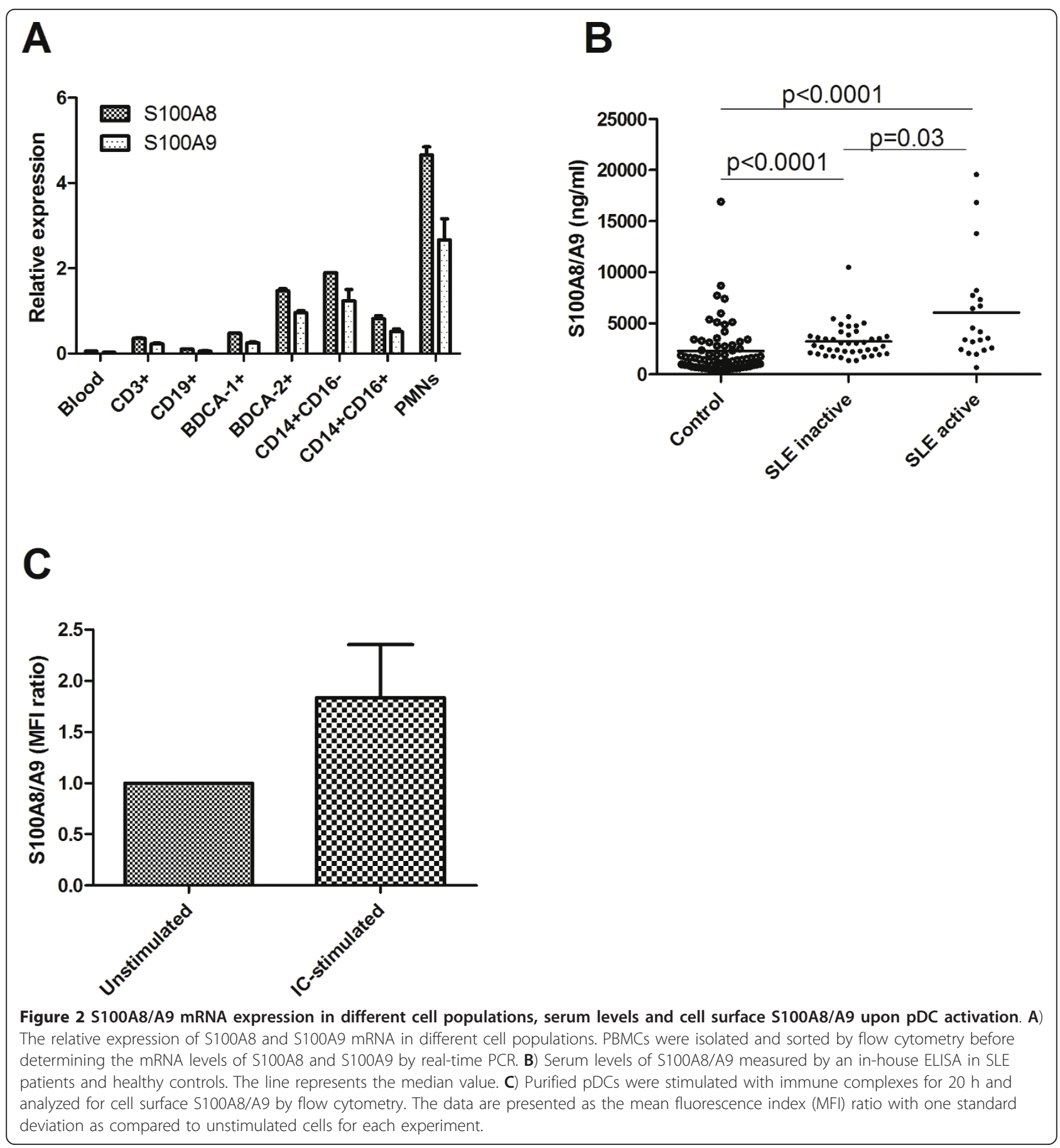

is important to assess numbers and activation status of the different leukocyte populations that we investigate for S100A8/A9 expression.

Despite the lack of S100A 8 and S100A9 mRNA in many leukocyte subpopulations, cell surface S100A8/A9 was detected by flow cytometry on all of the investigated cell populations except for $\mathrm{T}$ cells. It is known that the S100A8/A9 complex is produced by phagocytes such as monocytes and neutrophils [28] and we could verify by mRNA analyses that, among the cell populations studied, only monocytes, PMNs and also pDCs could produce S100A8 and S100A9. To our knowledge it has not previously been shown that $\mathrm{pDCs}$ are able to produce S100A8/A9. Interestingly, S100A8/A9 seemed to be actively transported to the outside of the membrane upon pDC activation suggesting that the cell surface 


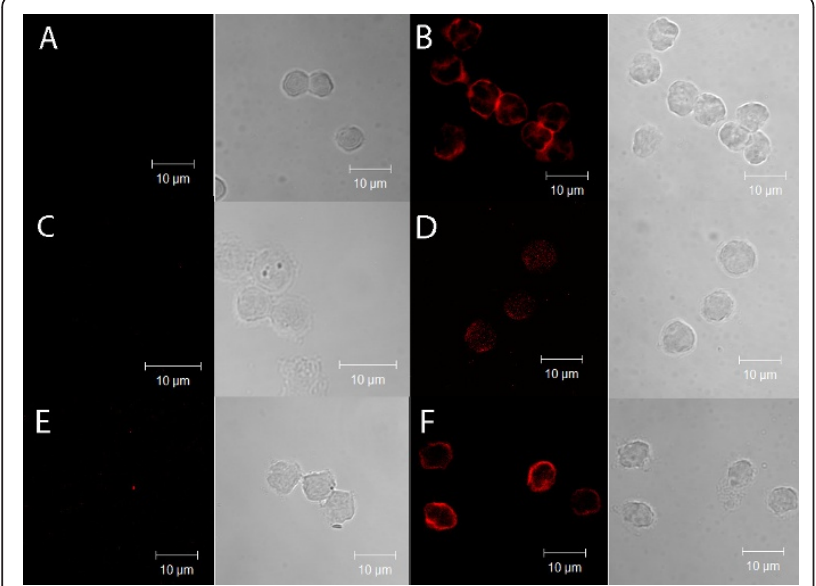

Figure 3 Analysis of S100A8/A9 staining in different leukocyte populations by confocal microscopy. Cells were isolated, fixed, permeabilized and stained for S100A8/A9 with the 27E10 antibody. $\mathrm{T}$ cells, B cells and $\mathrm{mDCs}$ ( $\mathbf{A}, \mathbf{C}$ and $\mathbf{E}$, respectively) had no detectable S100A8/A9 expression while PMNs, pDCs and monocytes (B, $\mathbf{D}$ and $\mathbf{F}$, respectively) had membrane-associated, as well as intracellular, S100A8/A9.

S100A8/A9 on pDCs indeed could have biological functions. The exact function of S100A8/A9 production in this particular cell remains to be shown, but the pDCs as an IFN $\alpha$ producing cell is clearly central in the pathogenesis of SLE. S100A8/A9 has been suggested to have several important functions in the immune system such as activation of monocytes, migration of myeloid derived suppressor cells and amplification of cytokine production [29-31,40]. Furthermore, cells from S100A9 deficient mice display reduced TNF $\alpha$ production when stimulated with LPS, a deficiency that could be restored by addition of extracellular S100A8/A9 [29]. Also, the S100A8/A9 complex can increase TNF $\alpha$ production upon LPS stimulation [29]. Recently, Björk et al. [32] described that quinoline-3-carboxamides or antibodies against S100A9 could inhibit the LPS-induced TNF $\alpha$ production. Recently, Loser et al demonstrated that S100A8 and S100A9 are crucial for the development of autoreactive $\mathrm{CD} 8^{+} \mathrm{T}$ cells and systemic autoimmunity in a mouse model [41]. Altogether, this illustrates that S100A8/A9 could serve as an amplifier of inflammation and should thus be regarded as a potential target for treatment of inflammatory diseases such as SLE.

Increased serum levels of S100A8/A9 in SLE, as well as in other connective tissue diseases such as rheumatoid arthritis and Sjogren's syndrome, was first described in 1990 by Kuruto et al. [42] and was later confirmed in SLE both in serum and by a proteomic-based study on PBMCs $[33,34,43]$. We could demonstrate increased serum concentrations of S100A8/A9 in SLE patients as compared to healthy controls and a correlation to disease activity. Cell surface S100A8/A9 was also increased on several leukocyte subpopulations such as pDCs in patients with active disease as compared to patients with inactive disease. However, the cell surface S100A8/A9 on some leukocyte subpopulations such as $\mathrm{B}$ cells and $\mathrm{mDCs}$ could not be explained by protein synthesis. Furthermore, it has previously been demonstrated that endothelial cells were coated with cell surface S100A8/A9 but lacked mRNA expression of these genes [44]. Clearly, other mechanisms also explain why S100A8/A9 are present on cell surfaces such as ligand up-regulation and deposition of S100A8/A9 from other sources such as serum or neutrophil extracellular traps (NET), which have a high content of S100A8/A9 [45]. High serum levels were, however, not generally associated with high cell surface S100A8/A9 levels. Furthermore, incubation of S100A8/A9 rich serum with leukocytes expressing low levels of S100A8/A9 on their surface could not increase the cell surface S100A8/A9 suggesting that the ligands most likely were already saturated. The broad binding pattern of S100A8/A9 to many cell populations indicates a general binding partner, and heparan sulfate glycosaminoglycans (GAG) structures and carboxylated glycans have been reported to bind to the S100A8/A9 complex as well as to the homodimer S100A9/A9 [44,46]. The low level or absence of cell surface S100A8/A9 on T cells would then suggest a specific GAG-structure epitope not present on T cells but otherwise commonly expressed on most leukocyte populations.

\section{Conclusions}

Here we could demonstrate the presence of S100A8/A9 on monocytes and PMNs as well as pDCs, mDCs and B cells, which are all cells that are important in the inflammatory response in SLE. We could demonstrate that pDCs, a cell population believed to be central in the SLE pathogenesis, could synthesize S100A8/A9 and express this protein on its surface upon activation. However, the exact function of S100A8/A9 is not fully understood and needs further studies. In fact, there are ongoing clinical trials in SLE performed by us using a quinoline-3-carboxamide compound targeting S100A9 which will give us more information on the role of S100A9 blockade in SLE and if it can be used as a therapeutic target.

\section{Abbreviations}

GAG: glycosaminoglycans; IC: immune complex; IFN: interferon; mDC: myeloid dendritic cell; MFI: mean fluorescence index; NET: neutrophils extracellular trap; PBMC: peripheral blood mononuclear cell; pDC: plasmacytoid dendritic cell; PMN: polymorphonuclear neutrophil; RAGE: receptor for advanced glycation end products; RNP: ribonuclear protein; SLE: systemic lupus erythematosus; TLR: toll like receptor. 


\section{Acknowledgements}

Maria Trulsson is acknowledged for excellent technical assistance with the confocal microscopy. The study was supported by grants from the Swedish Research Council (2008-2201), the Medical Faculty at Lund University, Alfred Österlund's Foundation, The Crafoord Foundation, Greta and Johan Kock's Foundation, King Gustaf V's $80^{\text {th }}$ Birthday Foundation, Lund University Hospital, the Swedish Rheumatism Association, Swedish Society of Medicine, Active Biotech $A B$, the Swedish Cancer Foundation and the Foundation of the National Board of Health and Welfare. The funding body had no part in the study design, the collection, analysis and interpretation of the data, writing of the manuscript or the submission.

\section{Author details}

'Department of Laboratory Medicine, Section of Microbiology, Immunology and Glycobiology, Lund University, Sölvegatan 23, 22362 Lund, Sweden. ${ }^{2}$ Department of Clinical Sciences, Section of Rheumatology, Lund University and Skåne University Hospital, Kioskgatan 3, 22185 Lund, Sweden. ${ }^{3}$ Department of Experimental Medical Science, Immunology Group, Lund University, Sölvegatan 19, 22184 Lund, Sweden.

\section{Authors' contributions}

$\mathrm{CL}$ carried out some of the flow cytometry, the confocal microscopy, pDC isolation and stimulation, performed the statistical analyses, participated in the design of the study and drafted the manuscript. MS carried out some of the flow cytometry and participated in the design of the study. HT and BG performed some of the ELISA analyses and revised the manuscript. EK performed the real-time PCR. TL, LT and GS participated in the design of the study and critically revised the manuscript. AB participated in the design of the study and helped to draft the manuscript and supervised the project. All authors participated in the design of the study, revised and approved the final manuscript.

\section{Competing interests}

Fl holds research grants from Active Biotech $A B$. $A B$ holds research grants and consulting fees from Active Biotech AB. MS is an employee of Active Biotech AB. TL is a part-time employee of Active Biotech AB. TL holds shares and stock options in Active Biotech AB. Active Biotech AB develops S100A9binding compounds for the treatment of autoimmune diseases.

Received: 17 December 2010 Revised: 10 March 2011

Accepted: 14 April 2011 Published: 14 April 2011

\section{References}

1. Manson JJ, Isenberg DA: The pathogenesis of systemic lupus erythematosus. Neth J Med 2003, 61:343-346.

2. Crow MK, Kirou KA: Interferon-alpha in systemic lupus erythematosus. Curr Opin Rheumatol 2004, 16:541-547.

3. Wei C, Anolik J, Cappione A, Zheng B, Pugh-Bernard A, Brooks J, Lee EH, Milner EC, Sanz I: A new population of cells lacking expression of CD27 represents a notable component of the B cell memory compartment in systemic lupus erythematosus. J Immunol 2007, 178:6624-6633.

4. Odendahl M, Jacobi A, Hansen A, Feist E, Hiepe F, Burmester GR, Lipsky PE, Radbruch A, Dorner T: Disturbed peripheral B lymphocyte homeostasis in systemic lupus erythematosus. J Immunol 2000, 165:5970-5979.

5. Viallard JF, Bloch-Michel C, Neau-Cransac M, Taupin JL, Garrigue S, Miossec V, Mercie P, Pellegrin JL, Moreau JF: HLA-DR expression on lymphocyte subsets as a marker of disease activity in patients with systemic lupus erythematosus. Clin Exp Immunol 2001, 125:485-491.

6. Wouters $\mathrm{CH}$, Diegenant $\mathrm{C}$, Ceuppens IL, Degreef H, Stevens EA: The circulating lymphocyte profiles in patients with discoid lupus erythematosus and systemic lupus erythematosus suggest a pathogenetic relationship. Br J Dermatol 2004, 150:693-700.

7. Jin O, Kavikondala S, Sun L, Fu R, Mok MY, Chan A, Yeung J, Lau CS: Systemic lupus erythematosus patients have increased number of circulating plasmacytoid dendritic cells, but decreased myeloid dendritic cells with deficient CD83 expression. Lupus 2008, 17:654-662.

8. Migita K, Miyashita T, Maeda Y, Kimura H, Nakamura M, Yatsuhashi H, Ishibashi H, Eguchi K: Reduced blood BDCA-2+ (lymphoid) and CD11c+ (myeloid) dendritic cells in systemic lupus erythematosus. Clin Exp Immunol 2005, 142:84-91.
9. Hepburn AL, Mason JC, Davies KA: Expression of Fcgamma and complement receptors on peripheral blood monocytes in systemic lupus erythematosus and rheumatoid arthritis. Rheumatology (Oxford) 2004, 43:547-554.

10. Bengtsson AA, Sturfelt G, Truedsson L, Blomberg J, Alm G, Vallin H, Rönnblom L: Activation of type I interferon system in systemic lupus erythematosus correlates with disease activity but not with antiretroviral antibodies. Lupus 2000, 9:664-671.

11. Baechler EC, Batliwalla FM, Karypis G, Gaffney PM, Ortmann WA, Espe KJ Shark KB, Grande WJ, Hughes KM, Kapur V, Gregersen PK, Behrens TW: Interferon-inducible gene expression signature in peripheral blood cells of patients with severe lupus. Proc Natl Acad Sci USA 2003, 100:2610-2615.

12. Bennett L, Palucka AK, Arce E, Cantrell V, Borvak J, Banchereau J, Pascual V: Interferon and granulopoiesis signatures in systemic lupus erythematosus blood. J Exp Med 2003, 197:711-723.

13. Crow MK, Kirou KA, Wohlgemuth J: Microarray analysis of interferonregulated genes in SLE. Autoimmunity 2003, 36:481-490.

14. Crow MK, Wohlgemuth J: Microarray analysis of gene expression in lupus. Arthritis Res Ther 2003, 5:279-287.

15. Han GM, Chen SL, Shen N, Ye S, Bao CD, Gu YY: Analysis of gene expression profiles in human systemic lupus erythematosus using oligonucleotide microarray. Genes Immun 2003, 4:177-186.

16. Mandel M, Achiron A: Gene expression studies in systemic lupus erythematosus. Lupus 2006, 15:451-456.

17. Lood C, Amisten S, Gullstrand B, Jönsen A, Allhorn M, Truedsson L, Sturfelt G, Erlinge D, Bengtsson AA: Platelet transcriptional profile and protein expression in patients with systemic lupus erythematosus: upregulation of the type I interferon system is strongly associated with vascular disease. Blood 2010, 116:1951-1957.

18. Kamphuis E, Junt T, Waibler Z, Forster R, Kalinke U: Type I interferons directly regulate lymphocyte recirculation and cause transient blood lymphopenia. Blood 2006, 108:3253-3261.

19. Lövgren T, Eloranta ML, Båve U, Alm GV, Rönnblom L: Induction of interferon-alpha production in plasmacytoid dendritic cells by immune complexes containing nucleic acid released by necrotic or late apoptotic cells and lupus IgG. Arthritis Rheum 2004, 50:1861-1872.

20. Vallin H, Blomberg S, Alm GV, Cederblad B, Rönnblom L: Patients with systemic lupus erythematosus (SLE) have a circulating inducer of interferon-alpha (IFN-alpha) production acting on leucocytes resembling immature dendritic cells. Clin Exp Immunol 1999, 115:196-202.

21. Båve U, Magnusson M, Eloranta ML, Perers A, Alm GV, Rönnblom L: Fc gamma Rlla is expressed on natural IFN-alpha-producing cells (plasmacytoid dendritic cells) and is required for the IFN-alpha production induced by apoptotic cells combined with lupus $\operatorname{lgG}$. $J$ Immunol 2003, 171:3296-3302.

22. Means TK, Latz E, Hayashi F, Murali MR, Golenbock DT, Luster AD: Human lupus autoantibody-DNA complexes activate DCs through cooperation of CD32 and TLR9. J Clin Invest 2005, 115:407-417.

23. Rönnblom L, Pascual V: The innate immune system in SLE: type I interferons and dendritic cells. Lupus 2008, 17:394-399.

24. Blanco P, Palucka AK, Gill M, Pascual V, Banchereau J: Induction of dendritic cell differentiation by IFN-alpha in systemic lupus erythematosus. Science 2001, 294:1540-1543.

25. Matikainen S, Paananen A, Miettinen M, Kurimoto M, Timonen $T$, Julkunen I, Sareneva T: IFN-alpha and IL-18 synergistically enhance IFN-gamma production in human NK cells: differential regulation of Stat 4 activation and IFN-gamma gene expression by IFN-alpha and IL-12. Eur J Immunol 2001, 31:2236-2245.

26. Marrack P, Kappler J, Mitchell T: Type I interferons keep activated T cells alive. J Exp Med 1999, 189:521-530.

27. Jego G, Palucka AK, Blanck JP, Chalouni C, Pascual V, Banchereau J: Plasmacytoid dendritic cells induce plasma cell differentiation through type I interferon and interleukin 6. Immunity 2003, 19:225-234.

28. Roth J, Vogl T, Sorg C, Sunderkotter C: Phagocyte-specific S100 proteins: a novel group of proinflammatory molecules. Trends Immunol 2003, 24:155-158.

29. Vogl T, Tenbrock K, Ludwig S, Leukert N, Ehrhardt C, van Zoelen MA, Nacken W, Foell D, van der Poll T, Sorg C, Roth J: Mrp8 and Mrp14 are endogenous activators of Toll-like receptor 4, promoting lethal, endotoxin-induced shock. Nat Med 2007, 13:1042-1049. 
30. Sunahori K, Yamamura M, Yamana J, Takasugi K, Kawashima M, Yamamoto H, Chazin WJ, Nakatani Y, Yui S, Makino H: The S100A8/A9 heterodimer amplifies proinflammatory cytokine production by macrophages via activation of nuclear factor kappa $B$ and p38 mitogenactivated protein kinase in rheumatoid arthritis. Arthritis Res Ther 2006, 8: R69.

31. Sinha P, Okoro C, Foell D, Freeze HH, Ostrand-Rosenberg S, Srikrishna G: Proinflammatory S100 proteins regulate the accumulation of myeloidderived suppressor cells. J Immunol 2008, 181:4666-4675.

32. Björk P, Björk A, Vogl T, Stenström M, Liberg D, Olsson A, Roth J, Ivars F, Leanderson T: Identification of human S100A9 as a novel target for treatment of autoimmune disease via binding to quinoline-3carboxamides. PLOS Biol 2009, 7:e97.

33. Haga HJ, Brun JG, Berntzen HB, Cervera R, Khamashta M, Hughes GR: Calprotectin in patients with systemic lupus erythematosus: relation to clinical and laboratory parameters of disease activity. Lupus 1993, 2:47-50.

34. Soyfoo MS, Roth J, Vogl T, Pochet R, Decaux G: Phagocyte-specific S100A8/A9 protein levels during disease exacerbations and infections in systemic lupus erythematosus. J Rheumatol 2009, 36:2190-2194.

35. Gladman DD, Ibanez D, Urowitz MB: Systemic lupus erythematosus disease activity index 2000. J Rheumatol 2002, 29:288-291.

36. Tan EM, Cohen AS, Fries JF, Masi AT, MCShane DJ, Rothfield NF, Schaller JG, Talal N, Winchester RJ: The 1982 revised criteria for the classification of systemic lupus erythematosus. Arthritis Rheum 1982, 25:1271-1277.

37. Lood C, Gullstrand B, Truedsson L, Olin Al, Alm GV, Rönnblom L, Sturfelt G, Eloranta ML, Bengtsson AA: C1q inhibits immune complex-induced interferon-alpha production in plasmacytoid dendritic cells: A novel link between $\mathrm{Clq}$ deficiency and systemic lupus erythematosus pathogenesis. Arthritis Rheum 2009, 60:3081-3090.

38. Schepis D, Gunnarsson I, Eloranta ML, Lampa J, Jacobson SH, Karre K, Berg L: Increased proportion of CD56bright natural killer cells in active and inactive systemic lupus erythematosus. Immunology 2009, 126:140-146.

39. Schlitt A, Heine GH, Blankenberg S, Espinola-Klein C, Dopheide JF, Bickel C, Lackner KJ, Iz M, Meyer J, Darius H, Rupprecht HJ: CD14+CD16+ monocytes in coronary artery disease and their relationship to serum TNF-alpha levels. Thromb Haemost 2004, 92:419-424.

40. Viemann D, Strey A, Janning A, Jurk K, Klimmek K, Vogl T, Hirono K, Ichida F, Foell D, Kehrel B, Gerke V, Sorg C, Roth J: Myeloid-related proteins 8 and 14 induce a specific inflammatory response in human microvascular endothelial cells. Blood 2005, 105:2955-2962.

41. Loser K, Vogl T, Voskort M, Lueken A, Kupas V, Nacken W, Klenner L, Kuhn A, Foell D, Sorokin L, Luger TA, Roth J, Beissert S: The Toll-like receptor 4 ligands Mrp8 and Mrp14 are crucial in the development of autoreactive CD8+ T cells. Nat Med 2010, 16:713-717.

42. Kuruto R, Nozawa R, Takeishi K, Arai K, Yokota T, Takasaki Y: Myeloid calcium binding proteins: expression in the differentiated $\mathrm{HL}-60$ cells and detection in sera of patients with connective tissue diseases. J Biochem 1990, 108:650-653.

43. Dai Y, Hu C, Huang Y, Huang H, Liu J, LV T: A proteomic study of peripheral blood mononuclear cells in systemic lupus erythematosus. Lupus 2008, 17:799-804.

44. Robinson MJ, Tessier P, Poulsom R, Hogg N: The S100 family heterodimer, MRP-8/14, binds with high affinity to heparin and heparan sulfate glycosaminoglycans on endothelial cells. J Biol Chem 2002, 277:3658-3665.

45. Urban CF, Ermert D, Schmid M, Abu-Abed U, Goosmann C, Nacken W, Brinkmann V, Jungblut PR, Zychlinsky A: Neutrophil extracellular traps contain calprotectin, a cytosolic protein complex involved in host defense against Candida albicans. PLoS Pathog 2009, 5:e1000639.

46. Srikrishna G, Panneerselvam K, Westphal V, Abraham V, Varki A, Freeze HH: Two proteins modulating transendothelial migration of leukocytes recognize novel carboxylated glycans on endothelial cells. J Immunol 2001, 166:4678-4688

doi:10.1186/ar3314

Cite this article as: Lood et al.: Protein synthesis of the pro-

inflammatory S100A8/A9 complex in plasmacytoid dendritic cells and cell surface S100A8/A9 on leukocyte subpopulations in systemic lupus erythematosus. Arthritis Research \& Therapy 2011 13:R60.

\section{Submit your next manuscript to BioMed Central and take full advantage of:}

- Convenient online submission

- Thorough peer review

- No space constraints or color figure charges

- Immediate publication on acceptance

- Inclusion in PubMed, CAS, Scopus and Google Scholar

- Research which is freely available for redistribution

Submit your manuscript at www.biomedcentral.com/submit 